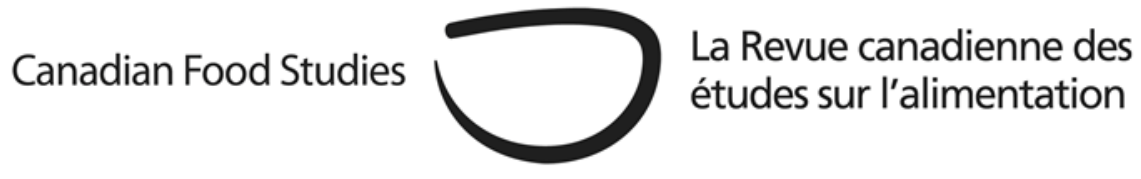

Original Research Article

\title{
Social economy of food initiatives that are nourishing communities through "power-with" practices
}

\author{
Mary Anne Martin ${ }^{a^{*}}$, Irena Knezevic ${ }^{b}$, Patricia Ballamingie ${ }^{b}$ \\ ${ }^{a}$ Trent University \\ ${ }^{\mathrm{b}}$ Carleton University
}

\section{Abstract}

From 2014 to 2019, Nourishing Communities: Sustainable Local Food Systems Research Group explored food initiatives in the social economy, many of which use practices like bartering, gifting, and self-provisioning, that remain under-recognized for their economic value.

Nourishing Communities considered how these organizations may contribute to food security, community development, and environmental remediation, especially for marginalized groups. Its researchers collaborated with such organizations to complete participatory action projects and a range of products to communicate the initiatives' impacts. As three of those researchers, we subsequently synthesized the material from these outputs to show the resources, barriers, and impacts of the respective initiatives. This meta-analysis reveals that these initiatives not only produce economic, social, and environmental benefits, but also work to organize human relations. Beyond considering how initiatives in the social economy of food interact with the market economy, we use Karlberg's schema of power to illustrate their potential to reconceptualize human relations. Here we find them gravitating towards "power with" practices that emphasize cooperation over competition. Throughout, we employ the concept of framing to propose ways in which that re-conceptualization might "grow legs" and extend further into larger social discourses. In so doing, we find the initiatives strategically invoking alternative framings of work, knowledge, social relations, and value in order to explain the impact of their own work. Although further research is needed regarding the meaning that impact and power hold for social

*Corresponding author: marymartin2@trentu.ca 
economy initiatives, this research contributes to scholarly debates surrounding the potential of food initiatives in the social economy.

Keywords: social economy; framing; neoliberalism; impact; power

Introduction

From 2014 to 2019, Nourishing Communities: Sustainable Local Food Systems Research Group (hereafter referred to as Nourishing Communities) has explored how food initiatives in the social economy function and contribute to food security, community development, and environmental impacts, especially for marginalized groups. Social economy has received greater attention from governments (Stephens et al., 2019), granting some community food initiatives greater legitimacy, but leaving others out of discussions, particularly those whose activities fall more under the informal economy umbrella. Activities like bartering, gifting, food sharing, seed exchanging, and self-provisioning are rarely seen as economic activities, though they are typically characterized by the same values and motivations as social economy. Consequently, Nourishing Communities works with both social and informal economy initiatives (see Table 1) and sees the lines between the two as blurred at times.

Throughout this work, we were cognizant of the importance of context in understanding social and informal economy. Geographical location, policy landscape, cultural context, and the purpose that drives each of these initiatives, all influence how they contribute to their communities. For instance, Canada's policy environment is different from that of some jurisdictions (e.g., Belgium, Portugal, Spain) that have laws to protect social economy. In addition, traditional forms of food sharing may be common in Indigenous communities, and rural and remote areas, but newer forms, such as those mediated through information and communications technology have begun to develop in urban environments (Davies, 2019). Moreover, a social enterprise that pursues social goals alongside profit may have to prioritize economic sustainability, whereas this is less of a concern for a community group that relies exclusively on volunteer labour. Nevertheless, as we demonstrate below, the commonalities across these initiatives are many. We blur the lines among the initiatives not to erase their specificities, but to highlight the collective value of their work.

Researchers within Nourishing Community's Social Economy of Food (SEOF) project worked closely with community organizations to develop case study reports, webinars, videos, an impact-focused workshop ${ }^{1}$, and scholarly articles, including the ones featured in this Canadian Food Studies journal special issue. Nourishing Communities' engagement in

\footnotetext{
${ }^{1}$ All available at Nourishing Communities (2018). The videos can also be viewed on the Laurier Centre for Sustainable Food Systems' YouTube Channel, at https://www.youtube.com/playlist?list=PLdtZB0Q09A3Ctrj5kAISVqugEX44QtXqX
} 
participatory action research projects with each community partner provided a deeper level of understanding while helping to support the goals of these organizations. Recently, the findings from this body of work have been summarized through a set of infographics. ${ }^{2}$

Overall, Nourishing Communities (2017a) set out to determine the mechanisms through which social economies:

1) increase prosperity for marginalized groups;

2) build adaptive capacity to increase community resilience;

3) bridge divides between elite consumers of alternative food products and more marginalized groups;

4) increase social capital; and

5) foster social innovation, entrepreneurship, and economic diversification.

This research agenda arose from numerous consultations among the research team members, and with existing community partners who had expressed interest in further collaborating with Nourishing Communities. Using terms like prosperity, products, entrepreneurship, and diversification, these questions evoke the priorities of capitalist economics and the dialect of a funding audience. They proved a pertinent line of inquiry, however, given that our community partners went on to emphasize their need to measure and communicate impact in ways that can be understood and valued by those who support the financial viability of projects. As we demonstrate across our research outputs, the SEOF initiatives have, in fact, demonstrated very real effects on their communities, local economies, and ecosystems, even if these effects are often challenging to quantify.

Conversely, as one community partner stated: "The measurements that we use don't measure the things that define the world that we live in" (Nourishing Communities, 2017b, p. 8). Simply stated, social economy initiatives struggled to communicate their other-than-monetary value(s) in monetary terms. At the same time, these partners sought to speak their truth in their own words (and to see it valued). They reiterated their need to articulate their less tangible and more complex impacts and goals, such as social capital, community building, and the experience of sharing food (Nourishing Communities, 2017b). Community partners and researchers alike recognize that such self-expression can seem a bit luxurious when insufficient funds threaten the very viability of many projects. However, they also recognize the importance of initiatives not losing their raisons d'être while trying to respond to funding constraints. Amidst such constraints, alternative food initiatives such as these must also endure scholarly charges of failing to transform prevailing economic and political systems (Allen, 2010; Guthman, 2008).

Given that monetary and non-monetary activity are interconnected, we first consider the monetary impacts of the social economy of food initiatives and then the challenges they face in measuring other forms of impact. We proceed to explore the less quantifiable significance that community partners were eager to illuminate. In so doing, we consider the multiple ways in

${ }^{2}$ Available at Nourishing Communities (2018) 
which the initiatives deploy power and shift dominant frames as they foster empowerment within and outside lines of equality, reinvest resources, use the power of naming, and choose pro-social and pro-environmental values over a need for control. Overall, the SEOF project suggests that, while much of the work of food initiatives in the social economy could and should be assigned monetary value and market importance, their greater contribution lies in the process of reconceptualizing human relations, a transformative pursuit that we will explore through the lens of power. In particular, we find the initiatives employing what Karlberg (2005) refers to as "power with" (p. 9) practices, those which encourage cooperation over competition. Our goal in this paper is to trouble the distinction between these seemingly competing economic and social goals and imagine how value can be reframed to better communicate the diverse contributions that social and informal economy initiatives make to their communities.

The social economy of food initiatives

A collection of 13 community partner organizations operating in the social economy of food sphere form the core of the SEOF project. They include cooperatives, not-for-profits, and social enterprises. Together their food activities span land preservation, seed saving, food production, harvest, processing, distribution, education, and advocacy. Table 1, below, provides context by briefly describing each of these organizations.

Table 1: Community Partner Organizations in the Social Economy of Food Project

\begin{tabular}{|l|l|}
\hline Name (in article) & Description \\
\hline $\begin{array}{l}\text { Algoma Highlands Wild } \\
\text { Blueberry Farm \& Winery, } \\
\text { (Algoma Highlands) Wawa, } \\
\text { Ontario }\end{array}$ & $\begin{array}{l}\text { commercial wild blueberry farm that sells blueberries and value-added blueberry products in its } \\
\text { storefront, through Cloverbelt co-op \& in various stores locally and out of area }\end{array}$ \\
\hline $\begin{array}{l}\text { Alternative Land Use } \\
\text { Services (ALUS), Eastern } \\
\text { Ontario }\end{array}$ & $\begin{array}{l}\text { non-profit program that supports farmers in dedicating portions of their land to nature by } \\
\text { retiring ecologically-sensitive land or land not suitable for farming }\end{array}$ \\
\hline $\begin{array}{l}\text { Aroland Youth Blueberry } \\
\text { Initiative (AYBI), Aroland } \\
\text { First Nation, Ontario }\end{array}$ & $\begin{array}{l}\text { self-organized initiative that buys excess wild blueberries from local people and then sells them } \\
\text { to raise money to support local youth programs }\end{array}$ \\
\hline $\begin{array}{l}\text { Arthur Shupe Wild Foods, } \\
\text { Dryden, Ontario }\end{array}$ & $\begin{array}{l}\text { family business that hires workers (including occasional passing hitchhikers) to harvest wild } \\
\text { blueberries and then sells them in bulk and at roadsides }\end{array}$ \\
\hline $\begin{array}{l}\text { Atlantic Canada Seed } \\
\text { Saving Projects, } \\
\text { Atlantic Canada }\end{array}$ & $\begin{array}{l}\text { multiple initiatives and groups including farmers, non-profits, and social enterprises who all save } \\
\text { seeds for the protection of culture, heritage, biodiversity, and food security, with focus on } \\
\text { Atlantic Canada }\end{array}$ \\
\hline $\begin{array}{l}\text { Black Duck Wild Rice (Black } \\
\text { Duck), Curve Lake, Ontario }\end{array}$ & $\begin{array}{l}\text { social enterprise dedicated to growing, harvesting, distributing, and teaching about wild rice } \\
\text { ("manoomin") as a fundamental food of Anishinaabeg people }\end{array}$ \\
\hline
\end{tabular}




\begin{tabular}{|c|c|}
\hline $\begin{array}{l}\text { Cloverbelt Local Food Co-op } \\
\text { (Cloverbelt), Dryden, } \\
\text { Ontario }\end{array}$ & $\begin{array}{l}\text { online food distribution network emphasizing fresh, local food, connections among/between } \\
\text { producers and consumers, and environmental sustainability }\end{array}$ \\
\hline $\begin{array}{l}\text { Durham Integrated } \\
\text { Growers for a Sustainable } \\
\text { Community }(D I G) \text {, Durham } \\
\text { Region, Ontario }\end{array}$ & $\begin{array}{l}\text { not-for-profit organization that supports, promotes, and advocates for local urban agriculture } \\
\text { practices and values }\end{array}$ \\
\hline $\begin{array}{l}\text { FarmWorks Investment Co- } \\
\text { operative Limited } \\
\text { (FarmWorks), } \\
\text { Nova Scotia }\end{array}$ & $\begin{array}{l}\text { for-profit cooperative that provides small loans to local food businesses through the Nova Scotia } \\
\text { government's Community Economic Development Investment Fund (CEDIF) program in order to } \\
\text { improve agricultural and food system sustainability }\end{array}$ \\
\hline $\begin{array}{l}\text { Guelph Centre for Urban } \\
\text { Organic Farming (GCOUF), } \\
\text { Guelph, Ontario }\end{array}$ & $\begin{array}{l}\text { certified organic university teaching farm of Ontario Agricultural College at University of Guelph } \\
\text { that is focused on sustainable agriculture }\end{array}$ \\
\hline $\begin{array}{l}\text { Hidden Harvest, } \\
\text { Ottawa, Ontario }\end{array}$ & $\begin{array}{l}\text { for-profit social enterprise that works to organize and normalize the harvest of urban fruits and } \\
\text { nuts while contributing to local food access, connections, and skills }\end{array}$ \\
\hline $\begin{array}{l}\text { Nipigon Blueberry Blast, } \\
\text { Township of Nipigon, Red } \\
\text { Rock Indian Band and Lake } \\
\text { Helen Reserve, Ontario }\end{array}$ & festival to raise community awareness of, respect for, and opportunities to pick wild blueberries \\
\hline $\begin{array}{l}\text { Willow Springs Creative } \\
\text { Centre (Willow Springs), } \\
\text { Lappe, Ontario }\end{array}$ & $\begin{array}{l}\text { social purpose, community-development centered enterprise offering arts, gardening, and food } \\
\text { programs and training. Includes horticultural therapy, local venders' market, and CSA-style } \\
\text { freshly prepared-food programs }\end{array}$ \\
\hline
\end{tabular}

\section{Conceptualizing social economy}

Before analyzing findings from the SEOF project, we briefly consider ways in which social economy, power, and frame analysis have been conceived. There is a variety of scholarly definitions of social economy, sometimes also referred to as the "third" sector (as distinct from private and public sectors). Many have identified the social economy's prioritization of social goals over or alongside market ones (Canadian CED Network, n.d.; McMurtry, 2010; Quarter \& Mook, 2010; Uluorta, 2009). Researchers have also debated the extent to which these initiatives interact with both the market economy and government. In the process, social economy is often defined by its contrast to the market economy. For instance, these organizations may represent a "non-capitalist form of production" (Uluorta, 2009, p. 170) or be understood as "economic activity neither controlled directly by the state nor by the profit logic of the market" (McMurtry, 2010, p. 4). Quarter and Mook (2010) argue, however, that social economy organizations are not, in fact, separate from the public and private sectors, but rather, show a shifting relationship with them, working sometimes in ways that are consistent with them and sometimes in ways that challenge them. Although social economies often emerge in response to the shortcomings of a market economy, McMurtry (2010) stresses that the genesis of this form in fact predates capitalism and can perhaps be best understood today by cultures that have retained a precapitalist worldview. He asserts, "Simply put, the idea of economic activity separate from social concerns is not one that is comprehendible to pre-market societies" (p. 19). 
Some authors have questioned the sheer utility of defining social economy initiatives through their adherence with discreet organizational forms. For example, while acknowledging that form is still important, McMurtry (2010) contends that, "the social economy is fundamentally a normative concept, then, and its practice should be defined as such, not by applying taxonomic definitions to it" (p. 29). ${ }^{3}$ Furthermore, Mount and Andrée (2013) find "community-based food projects" (p. 579) 4 to a large extent exist as hybrids "that often blur the lines between governmental, public, non-profit, cooperative, multi-stakeholder and private" ( $p$. 578). They suggest that this hybridity may operate as a strength, possibly representing "what works, an example of what might be termed "post-neoliberal" food governance" (p. 588).

Initiatives in the social economy are assessed in a variety of ways. For example, to demonstrate their impact to funding and oversight bodies, they apply metrics such as number of people fed, amount of food grown, or number of people acquiring specific skills. McMurtry (2010) recommends a more pointed assessment of social economy initiatives based on their ability to fulfill ethical imperatives of meeting "life-needs" (p. 29). On a broader scale, however, they are also assessed for their ability to effect political, societal and economic transformation and to contribute to state accountability (Allen, 2010; Delind, 2011; Guthman, 2008; Wakefield, Fleming, Klassen, \& Skinner, 2013).

\section{Perspectives on power}

Meeting human needs and effecting transformation inherently require attention to the power dynamics in which organizations play a role. Feminist post-structuralists regard power as ubiquitous, relational, and dynamic rather than held in the custody of particular entities (Gannon \& Davies, 2012). This dynamic perspective of power-in-motion (rather than power possessed) opens the possibility of agency from even the most vulnerable and of change from seemingly intractable conditions. However, feminist scholars such as Hartsock (1989) and Kruks (2001) caution against the potential they see in post-structural perspectives such as those of Michel Foucault and Richard Rorty to dissolve institutional structures, and to render political analysis difficult and power dynamics such as women's subordination invisible.

Karlberg (2005) also considers power to be relational and active by considering it in terms of the equality of parties involved and their way of relating to each other. He has recognized deleterious social, political, and environmental effects emerging from a narrow,

\footnotetext{
${ }^{3}$ By "normative," McMurtry is referring to "the belief that economic, philosophical, or social norms (standards or rules of behaviour or practice, whether conscious or unconscious) should exist. To argue that a particular idea or behaviour is normative is to argue that it is good or proper - that one ought to behave in [a] particular way" (p. 31).

${ }^{4}$ Mount \& Andreé (2013) regard community-based food projects as one form of alternative food networks that focus on food distribution as well and social, community and environmental goals.
} 
hegemonic definition of power as rooted in conflict and exhibited in domination or "power over." In fact, he says,

What I am suggesting is that conflict should not continue to serve indefinitely as the normative principle upon which we construct our governing institutions and conduct our affairs, as it currently does in Western-liberal societies, where democracy is confused with partisanship, where justice tends to be confused with legal contestation, and where economy is confused with competitive material acquisition (Karlberg, 2005, p. 15).

Table 2. Power: A Unified Schema (Source: Karlberg, 2005, p. 10)

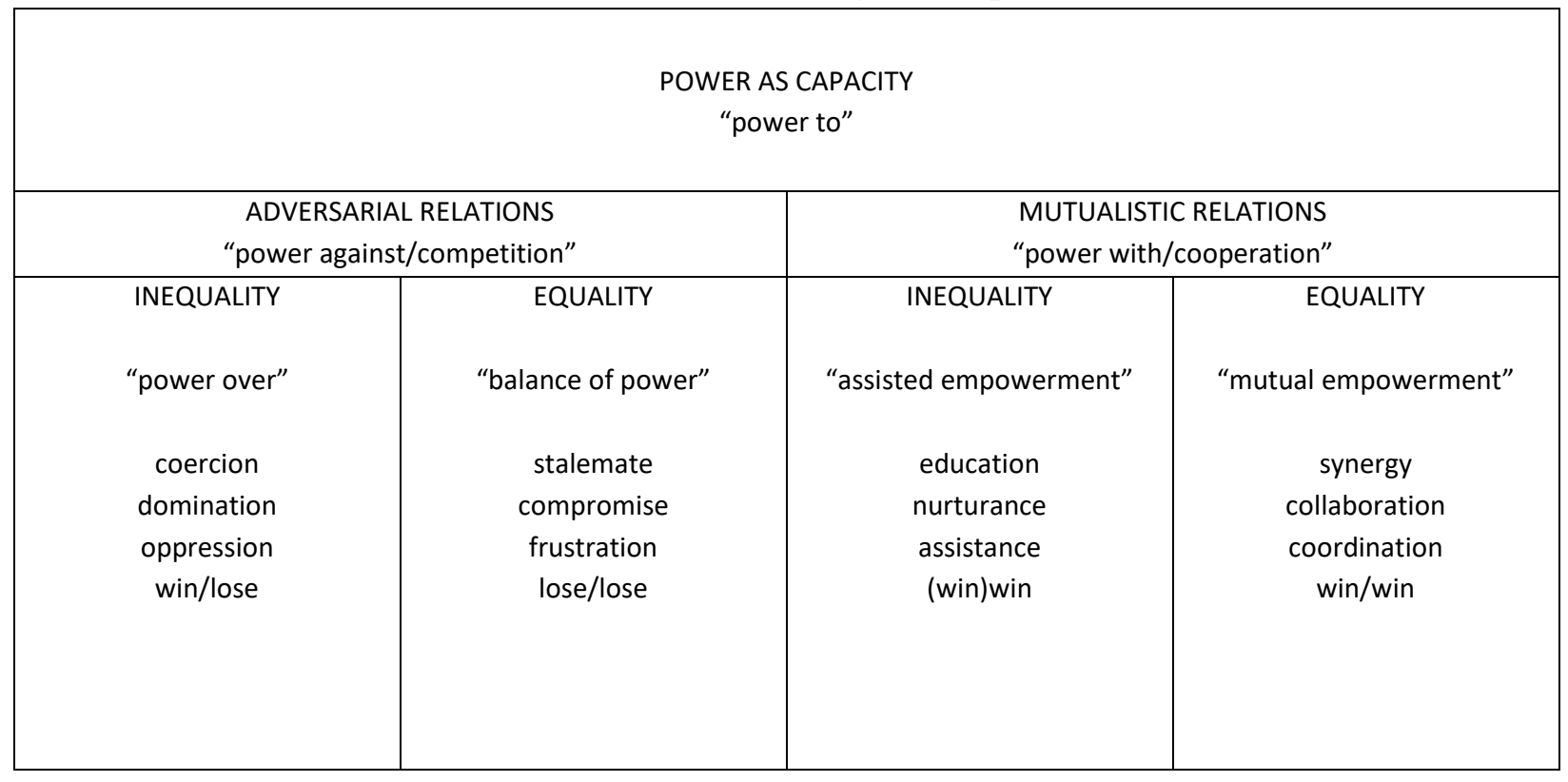

Karlberg (2005) has developed a schema based on the view of power as a form of capacity or "power to" (see Table 2). He then organizes power along two axes. First, he sees a continuum of relations that extends from working against each other in competition to working with each other in cooperation. Second, within each category of relations, he sees a continuum of resource distribution, from inequality to equality. The application of both axes results in four forms of power. The first, competitive and unequal ("power over"), is visible through "coercion, domination, oppression, and a win/lose dynamic." The second, competitive and equal ("balance of power"), results in forms of resignation through "stalemate, compromise, frustration, and a lose/lose dynamic." The third, cooperative and unequal ("assisted empowerment") can be seen in helping people with fewer resources through "education, nurturance, assistance" and positive, though perhaps differentially so, outcomes for both parties. The fourth, cooperative and equal ("mutual empowerment"), can be seen in "synergy, collaboration, coordination," and positive outcomes for both parties. Karlberg's schema demonstrates that "power over" constitutes only one of several forms of power. As such, it dispels assumptions of human nature as innately competitive/adversarial and instead opens possibilities for more pro-social ways of exercising 
power and benefitting from these practices. We see Karlberg's schema as a useful framework for considering the mobilization of power among the SEOF initiatives. ${ }^{5}$

\section{Framing and power}

The mobilization of power is facilitated or impeded through the framing of concepts. Frame analysis considers the ways in which social issues are framed, or socially constructed. Frames are "principles of selection, emphasis and presentation composed of little tacit theories about what exists, what happens, and what matters" (Gitlin, 1980, p. 7). Framing makes certain aspects of social reality more salient than others, emphasizing particular interpretations of an issue over others (Entman, 1993, p. 52). As a social process, framing is greatly shaped by those who control or influence the discourse surrounding the issue at hand. That discourse can take shape in complex forms (providing context for an issue) or simple word choices that subtly imply values (e.g., using "gray economy" to refer to informal economy). Frame analysis allows for a deconstruction of frames, including an examination of how frames come into existence and to what effect. If we understand frames as "the result of socially situated articulations between particular issues, individual and collective differences, experiential knowledge, popular wisdom and media discourse" (Vliegenthart \& van Zoonen, 2011, p. 105) and thus greatly shaped by social dynamics, we can see that frame analysis permits tracing of the patterns of power and how they are reflected in discourse. While we focus on power relations, our investigation is partly informed by frame analysis in order to uncover the potential of social economy initiatives to influence more than just their immediate environments.

\section{Methodology}

This research involved a meta-analysis of the case studies, videos, webinars, and reports from the Social Economy of Food project. We organized the material from these outputs to examine the resources, barriers, and impacts of the respective initiatives. Throughout this process, the most salient categories to emerge included:

- Description of the initiative

- Focus of the initiative

- Philosophy/Approach

- Resources- Human

- Resources- Partnerships

- Resources- Financial

- Resources- Physical

\footnotetext{
${ }^{5}$ For an exploration of another model of power and how it relates to governance processes in food movements, see Andrée, Clark, Levkoe, Lowitt, \& Johnston (2019).
} 
- Resources- Knowledge

- Resources- Social

- Products

- Impacts- Economic

- Impacts- Social

- Impacts- Knowledge

- Impacts- Environmental

- Impacts- Others

- Barriers to meeting goals

- Goals

As the categories were defined, all materials were reviewed for content corresponding to these categories. They were also reviewed for information around existing, expected, and desired forms of evaluation. Although some content was found for existing evaluation, only one initiative spoke of desired evaluation and none spoke to expected evaluation.

We teased out themes across the case studies which we illustrated through a set of infographics (see footnote 2) — and then solicited feedback on these images from our Nourishing Communities community of scholars and partners. Throughout this process, the organization of human relations emerged as a central theme. We consider how the social economy of food initiatives impact the market economy and then use Karlberg's schema of power as a guide to illustrate their potential to reconceptualize human relations. Throughout, we draw on the concept of framing to propose some ways in which that reconceptualization might "grow legs" and extend further into larger social discourses.

\section{Results}

While the meta-analysis of the SEOF project generates insights into the monetary impacts of the initiatives and the challenges of assessing non-monetary impacts, it more importantly reveals the ways that initiatives reframe human relations through mobilizing power with. By fostering mutual empowerment, assisted empowerment, reinvestment of resources, naming practices, and the choosing of pro-social/pro-environmental values over control, the initiatives reconceptualize the ways that humans relate to each other and ecosystems.

\section{Assessing market impact: Valuing what is undervalued}

To begin, we consider a major lens through which initiatives in the social economy of food are assessed: their monetary significance in a market economy. Mainstream neoliberal framing of value as principally monetary often requires social economy endeavours to demonstrate their 
value in those terms, particularly when speaking to funders, investors, and various levels of government.

The monetary contribution of some initiatives is evident. For example, FarmWorks draws on community investments and the provincial government's Community Economic Development Investment Fund program to provide loans to local food businesses across Nova Scotia. Similarly, Cloverbelt facilitates an online producers' market in Northern Ontario through a co-op model, while Algoma Highlands operates a commercial wild blueberry farm - both with clearly quantifiable benefits. Some of the initiatives, like Hidden Harvest and Cloverbelt, generate profits, but overall, the movement of financial capital in all these initiatives is visible to varying extents.

In addition, some initiatives assign a monetary value to that which has previously been under/unvalued, to demonstrate that even without financial capital their activities have economic value. For instance, Hidden Harvest has developed ways of assigning monetary value to previously untapped urban fruit and nut yields - spinning gold from straw, so to speak, while ALUS provides compensation to farmers for their land stewardship. Furthermore, some initiatives raise money for marginalized groups (AYBI for youth programming; DIG for new urban agriculture projects) or provide incomes for marginalized groups (Willow Springs for people with employment barriers).

Social economy initiatives' contributions to the market economy may also be less visible, but no less real. For instance, their value may be found in the ways that they provide otherwise publicly-funded services by addressing issues of, for example, food security/health (all of the initiatives), waste management (GCUOF, Hidden Harvest), environmental restoration (ALUS, Black Duck, DIG, GCUOF), or public policy analysis (DIG). Some initiatives help to boost local economic development by, for instance, creating local jobs or income sources (Algoma, ALUS, Arthur Shupe, AYBI, Cloverbelt, FarmWorks, GCUOF, Hidden Harvest, Willow Springs), partnering with value-added processors (Cloverbelt, Hidden Harvest), paying living wages (Hidden Harvest), and promoting tourism (Algoma Highlands, Nipigon Blueberry Blast). Many also buy local goods and services and some pay municipal taxes. They also raise the visibility, recognition, and trust of producers and their products leading to increased sales and higher incomes for producers.

Finally, some initiatives work to remove resources from a commoditized framework and return them to the commons. For example, Black Duck Wild Rice reclaims cottage-front segments of local lakes for First Nations community food production (though not without controversy). Overall such impacts may prove challenging to calculate but organizations like Hidden Harvest are developing means such as Social Return on Investment (SROI) tools to provide monetary proxies, as a strategy to redefine (and re-frame) what is deemed to be economically valuable. 


\section{The challenges of measuring (extra-market) impact}

As discussed, various initiatives find it challenging to measure and articulate their extra-market impact(s) in ways that can be appreciated and supported, especially by funders. As reported in the Black Duck Wild Rice case study,

Black Duck is not just about generating money, although that is part of it. It is also about creating collective prosperity and wealth through enriching the social, cultural, spiritual and environmental aspects of the community (Anderson \& Whetung, 2018, p. 31).

When impacts extend beyond market value to factors like food sovereignty, selfdetermination, cultural resurgence, and community relations, this challenge is heightened. Most of the case studies revealed few or no measurements of collective impact. The Hidden Harvest case study report was one of the few to share quantified impacts such as: number of harvest events over time; number of active volunteers; and pounds of produce harvested, processed, donated and distributed. Nonetheless, "Hidden Harvest's aim to enhance local economies remains a long-term project, and their impacts are not easily measured through conventional conceptualizations of economic values" (Poitevin-DesRivières, 2018, p. 18).

We suspect that the case studies' relative absence of quantitative measures of impact is unsurprising, given four conditions. First, social economy organizations by their very nature focus heavily on social and environmental impacts, which are inherently more difficult to capture and quantify than economic ones. For example, as identified in the GCUOF case study:

Another employee at GCUOF noted that one thing often missing from the measure of a healthy economy is the value of mental health. While many believe that the Canadian economy should be focused on the quantity of production or the amount of money being generated, it is often the quality of one's work or what employees spend their time doing that contributes to positive mental health. Working on an organic farm and interacting with the natural world can help one feel more connected. Being outside and doing physical labour can be both emotionally and physically beneficial. Although those things are not generally accounted for in the measure of a healthy economy, they should be taken into consideration (Thomas, 2015, p. 13).

Second, the tasks of defining, collecting, organizing, analyzing, and disseminating measures of impact requires human labour, something that is scarce and undercompensated among many of the social economy organizations. This results in a chicken-and-egg situation: many organizations must prove their impact to merit necessary funding, but they often have limited resources to devote to this work.

Third, for some initiatives the collection of impact measurement can seem meaningless. For example, GCUOF's affiliation with the University of Guelph limits the initiative's eligibility 
for many grants (personal communication, Jan. 23, 2019). For some, like DIG, who do not have registered charitable status (or the goal of applying for grants), the effort of collecting such data may seem to serve little purpose. The labour of collecting measurements and then using them to complete grant applications also needs to be weighed against the likelihood and value of being awarded those grants.

Finally, aside from the impracticalities of measuring impact, it seems that some organizations resist it based on competing principles. For instance, DIG's commitment to the autonomy of its projects makes the organization reluctant to ask the projects to collect a standard set of data. Similarly, a member of GCOUF notes: "[impact measurement is] not something I've had the time to do, or maybe even the desire to do because MY impact is one-on-one at the farm. That impact I guess could be measured but isn't. It's measured through the sharing of knowledge" (personal communication, Jan. 23, 2019).

The initiatives make certain assumptions about basic human rights, positing, for example, that people should: have access to sufficient nutritious food; be able to participate in community life; and be able to look to a future with healthy land, air, and waterways. They re-center the fulfillment of basic physical, social, economic, and environmental needs through the use of seldom-contested and time-honoured values such as respect, reciprocity, and cooperation. This normative position corresponds with McMurtry's (2010) view that the social economy decentres market goals and normalizes activities that demonstrate how people ought to engage with one another and the environment to fulfil their "life-needs" (p. 29).

Given such frames for their work, we suspect that the absence of substantial impact measurements may at times be less reflective of limited capacity and more reflective of a rejection of neoliberal framings of value. In other words, we wonder if the organizations not only grapple with the means of measuring impact but also with the meaning of measuring impact as obliging them to prove the indisputable or to counter other, damaging impacts (e.g. of colonization, privatization, pollution, or austerity politics). In this way, we wonder if initiatives may resist such measurement as an affront to their sensibilities and values. When organizations regard their goals as fundamental and morally legitimate, it is unsurprising if they sometimes balk at having to prove the value of pursuing them.

\section{Towards power as capacity}

Part of the struggle to articulate impact may emerge from initiatives' emphasis on process over product. According to McMurtry (2010), "the defining feature of capitalism is its constant delinking of the economic from the social" (p. 19) through a focus on individualism, self-interest in the market, and profit maximization. While the social economy initiatives certainly demonstrate value in the dominant economic system, they also re-signify what is deemed economic by reframing people as social beings who are interconnected with each other and the natural world. It can be challenging to measure the impacts of social processes such as the quality of relationships 
or the feelings of connection and well-being. But much more than monetary value, these initiatives' contributions to such harder-to-quantify social impacts reveal their acuity for reshaping human relations and the ways in which power is organized through them.

If power is understood only as domination, then the initiatives, given their challenges in accessing established forms of financial, human, and political capital, may seem to experience a lack of power. However, if power is reframed as capacity, and particularly the potential to ameliorate the conditions in which humans live, then the power of these initiatives is much more evident. Clearly, they operate primarily on the cooperative, or "power with," side of Karlberg's (2005) schema (Table 2). That is, they promote "mutual empowerment" in their work with groups of similar social standing and "assisted empowerment" in their work with more marginalized groups. Beyond Karlberg's typology, however, we suggest that they also exercise power by advocating on behalf of themselves and groups of various social statuses to actors with decision-making abilities, such as government bodies. In so doing, they extend their impact beyond their own surroundings and aim to shift the discourse around value.

\section{Cooperative power across equality: "mutual empowerment."}

A sense of connection constitutes one of the most visible characteristics of the initiatives. Karlberg's "mutual empowerment" can be seen in the ways in which they promote social capital by fostering bonds between similarly situated actors and bridges between differently situated actors (Putnam, 2000). This sense of connection corresponds well with Uluorta's (2009) contention that social economy activities are focused on "being-in-the-world-with-others" ( $p$. 170) and Sonnino and Trevarthen-Griggs' (2013) findings that building social capital can itself be a central goal and a key resource for social economy initiatives. The social economy organizations we studied develop social capital through using pro-social values such as inclusion, respect, reciprocity, reconciliation, accountability, collectivity, and cooperation. As an example, the Black Duck Wild Rice case study notes, "Responsibility and reciprocity is the foundation on which Black Duck bases its ecosystem and therefore cultural restoration work" (Anderson \& Whetung, 2018, p. 22). Organizations bring together farmers (ALUS, GCUOF), gardeners (DIG, Willow Springs), harvesters (Arthur Shupe, Hidden Harvest, Nipigon Blueberry Blast), entrepreneurs (AYBI, Cloverbelt, Nipigon Blueberry Blast, Willow Springs), seed savers (Seed Saving), and local community members (most initiatives). As examples of bridging, the SEOF initiatives bring people together across axes of difference such as: age (GCUOF works with university students, high school students, and daycare children); Indigenous and settler communities (Black Duck); and role (farmers, staff, advisors at ALUS). Both Cloverbelt and seed saving initiatives also foster relationships among different geographical communities.

Notably, we found evidence that initiatives subvert the capitalist principle of competition in favour of principles of cooperation and respect. For instance, Atlantic seed savers value healthy seed systems enough to share their knowledge with competing groups; Cloverbelt 
encourages cooperation rather than competition between vendors and avoids imposing itself in individual communities to preclude competing with local producers, and Arthur Shupe carefully respects the areas of competing blueberry picking initiatives (Stolz, Levkoe, \& Nelson, 2017; Streuker, Levkoe, \& Nelson, 2017; Worden-Rogers, 2015).

Not only do the initiatives bring people together across difference, fostering inclusion and social diversity, but they also go beyond an anthropocentric perspective to promote biodiversity and more resilient ecologies by creating healthier soil, conserving resources, reducing waste, contributing to cleaner air/water/soil/land, and saving seeds that are adapted to place and climate (ALUS, Black Duck, DIG, Seed Saving). In other words, they are re-framing people's relationships as responsible to "others"- both human and non-human.

\section{Cooperative power across inequality: "assisted empowerment"}

Among the social economy initiatives, assisted empowerment, Karlberg's second form of power, is evident in the origins of knowledge and decision-making, the distribution of knowledge, and efforts to meet people's needs. While the reciprocal nature of relationships is apparent in mutual empowerment discussed above, it is less apparent in assisted empowerment. However, the initiatives regard benefits as extending far beyond those who are ostensibly assisted.

In many cases, decision making and knowledge gathering derive from those most affected. For example, the case studies show ALUS to be "community-developed, farmerdelivered" (Allen, 2015, p. 5); AYBI to be "self-organized" (Stolz et al., 2017, p. 8) and "community-based and community-driven" (p. 10); and DIG to be "citizen-driven" (Martin, 2016, p. 17). Organizations prioritize the voices of farmers, gardeners, vendors, and community members - in essence, those who not only have the most lived experience and intimate understanding of the issues, but also have the most at stake. They challenge the assumption that "expert" or "evidence-based" knowledge(s) reside only within institutions, bringing to the fore other knowledge(s) that are experiential, shared, and community-based. For some, like Black Duck Wild Rice, knowledge gathering is a process of reclaiming what has been lost over generations through, for example, the effects of Canada's residential school system.

Furthermore, initiatives make knowledge accessible through such means as workshops, trainings, publications, websites, videos, social media, and opportunities for hands-on experiences (ALUS, Black Duck, DIG, Cloverbelt, GCUOF, Hidden Harvest, Nipigon Blueberry Blast, Seed Saving, Willow Springs).

Community partners in this project offered multiple reasons for sharing knowledge. For Black Duck Wild Rice, it is a matter of not losing what is left of traditional knowledge: "knowledge just slips away if it's not being used and engaged with" (Anderson \& Whetung, 
2018, p. 32). Patrick Kelly at GCUOF links knowledge dissemination with skill-building and broader transformation: "to teach people that they are able to grow their own food...that in a way is a form of quiet social and political change" (Thomas, 2015, p. 19). Part of Hidden Harvest's reason for sharing knowledge is to help support local producers by cultivating "more appreciation for what it takes to grow and harvest food, and many would consequently pay more for local foods" (Poitevin-DesRivières, 2018, p. 17). Through knowledge sharing, DIG hopes "to build a policy landscape that is representative and supportive of local urban agriculture projects" (Martin, 2016, p. 25) while the Atlantic seed savers endeavour to connect people and develop resilience at the community level.

Assisted empowerment also emerges in the initiatives' efforts to meet human needs such as sufficient income (ALUS, Cloverbelt, FarmWorks, Hidden Harvest, Willow Springs), household food security (Arthur Shupe, Black Duck, DIG, Hidden Harvest), skill-building (ALUS, AYBI, Black Duck, DIG, GCUOF, Hidden Harvest, Seed Saving, Willow Springs), and self-expression (Willow Springs). DIG and its member projects provide an example by assisting people's empowerment through open memberships, sliding fees, food donations, help for inexperienced gardeners, and culturally diverse produce. By emphasizing assisted empowerment, these initiatives recentre an ethic of human care for each other and reframe value as inclusion. Finally, assisted empowerment is evident in the representation of the needs and concerns of residents to governmental authorities regarding issues such as urban agriculture policy (DIG) and Ministry of Natural Resources herbicide spraying (Nipigon Blueberry Blast). Through the empowerment of people, these practices reframe the dominant views of "power over" as "emanating from the ground up".

By sharing knowledge with community members, helping to address their basic needs, and advocating for them, all the while drawing on the community expertise and decision-making, social economy initiatives work to revalue human agency and an ethic of care. They help to create stronger, more sustainable communities, and ultimately reveal that assisting individuals has ripple effects.

\section{Power as cyclical (versus linear)}

In addition to Karlberg's forms of power-with, we find other conceptualizations of power among the initiatives that counter capitalist logics. For instance, a capitalist preoccupation with linear trajectories of increased profit conceals the human and environmental sacrifices or 'externalities' that fuel them. Decades of capitalist social organization have framed human activities as selfinterested actions aimed at amassing material capital. However, through a social economy perspective that prioritizes social and environmental goals over profit, the organizations protect and nourish their inputs and redistribute their surpluses. For instance, the organizations return organic materials back to the soil (DIG, GCUOF) and redistribute harvested food back to the 
community (Black Duck, DIG, Hidden Harvest). They also return proceeds back into gardens (DIG), community groups (AYBI), education (Black Duck, DIG, Nipigon Blueberry Blast), training (Hidden Harvest, Willow Spring), and living wages (Hidden Harvest).

As an example, Cloverbelt producers pay 5 percent of their profits and consumers pay 10 percent of the purchase price towards operations, external funding for projects, and growth (CLFC webinar). Indeed, the Hidden Harvest case study states, "as a social enterprise, Hidden Harvest generates profits that are intended to benefit as many people as possible. Harvest events and outreach activities aim to enhance community food security and sovereignty, local ecologies and economies" (Poitevin-DesRivières, 2018, p. 3). Such activities re-frame human communities as complex entities that are motivated by much more than just self-interest.

\section{Power through language/the ability to name}

Language is another site where the initiatives mobilize power in ways that counter capitalist logics. The language of capitalism, like any regime, serves to reinforce itself. For instance, the business of destroying forests and meadows to construct buildings is commonly referred to as "development." That framing has greatly shaped and justified policy and political agendas, and the resulting relationships among human communities, and between humans and ecosystems. Feminist scholars (e.g. DeVault, 1990; hooks, 1991) have long identified the power of naming to illuminate underrepresented people, work, actions, and ideologies - and, in the process, shape their realities. Social economy initiatives also exert power through their use of language. They playfully promote social inclusion through team member titles such as Willow Spring's "Souper Heroes" (Kakegamic, Nelson, \& Levkoe, 2017) and Hidden Harvest's "Lead Squirrel" (PoitevinDesRivières, C., 2018). They insist on using traditional terms (Black Duck Wild Rice's manoomin for wild rice) to resituate food in social and natural systems. In addition, they demand definitions that reflect their communities' realities, such as DIG's expansive and regionallyspecific definitions of urban agriculture. As discussed earlier, they also name some resources as having monetary value and name others as uncommodifiable — belonging to the commons.

Such re-framing by initiatives does not only work to legitimize their own actions, but also encourages us to think of economy as much more complex than monetary exchanges. Their efforts to attach monetary value to some of their contributions challenge us to see mainstream economic accounts as both limited and limiting — as neglecting a broad range of initiatives and, in so doing, hindering their ability to prove their worth and worthiness of support. The insistence of initiatives on valuing what cannot be monetized demands consideration of the broader range of informal activities that cannot be measured in dollars but undeniably contribute to community well-being. 


\section{Power as seemingly waived}

A final approach to power by the initiatives may not seem to resemble power mobilization at all. Contrary to the popular perception of power as possessing or exerting control over, we observe that the organizations often exercise power when they seemingly relinquish it. Their work remains vulnerable to myriad forces beyond their control: weather, pests, funding, government policy and practices (such as herbicide spraying), and the personalities and capacities of their members - and yet, they persist. As the Black Duck Wild Rice experience shows, power can seem to be relinquished through deciding to trust in people, values, and process: "It is a lot of responsibility and quite exhausting to trust in, maintain and expand relationships in a good way, while engaging the community and communicating goals and aspirations" (Anderson \& Whetung, 2018, p. 37). By being responsive to their members and communities, adaptable to prevailing conditions, and resolved to pursue social impacts over profit, project proponents illuminate their priorities and their choice to embody specific values and ways of being in the world. In so doing, they choose trust and hope over despair and, in the process, may create new imaginaries/realities.

Power through vulnerability is shown when Black Duck rejects the pursuit of immediate security that a neoliberal discourse of scarcity might encourage. Instead Black Duck's owneroperator leaves more wild rice behind in the lakes for wildlife than he harvests, and forgoes his own living wages for the greater purpose of re-establishing a traditional food supply. Likewise, Guelph Centre for Urban Organic Farming cuts the ostensible life lines of oil, pesticides, and machinery to bring the idea of urban organic farming into reality (GCUOF). Similarly, DIG does not build gardens but supports community groups who ask for that help. The organization prioritizes the messiness of supporting self-determination for community garden groups to help projects become more sustainable. By seemingly relinquishing control, initiatives speak loudly about their choice to trade in central frames of self-interest, power-over, and immediate gratification for collectivity, power-with, and sustainability.

\section{Discussion and conclusion}

Food initiatives in the social economy and the informal practices that they use, such as bartering, gifting, and self-provisioning, exist in spaces of varying and debated distance from the private and public sectors. As such, their economic nature goes underrecognized. Nourishing Communities researchers have worked with several such initiatives in Canada to identify and illuminate their economic, environmental, and social impacts through participatory action research projects, case study reports, articles, webinars, and videos. This paper draws on a meta- 
analysis of these outputs to consider what these initiatives collectively say about the impacts of the social economy of food in a neoliberal era.

Neoliberalizing discourses shape human relations through frames such as self-interest, profit obsession, market reliance, scarcity, and the absence of alternative ways of structuring society. They are fortified by their "self-evident" and "self-actualizing" (Peck \& Tickell, 2002, p. 382) harmony with politically and economically dominant forces. This context can make impact assessment a challenging endeavour for organizations that prioritize social impacts over profit. Nonetheless we found clear indications that these initiatives in the social economy of food contribute in multiple direct and indirect ways to the market economy.

However, we observe that the initiatives contribute more substantially to broadening social imaginaries by challenging neoliberal interpretations of the ways humans relate with each other and the natural world. The application of Karlberg's typology of power, informed by frame analysis helps to make this visible. For instance, by cultivating both mutual and assisted empowerment, these organizations discursively re-centre an ethic of care, agency, inclusion, interconnection, recognition of multiple sources of expertise, and people's collective responsibility to each other and the natural world. By reinvesting their surpluses, the organizations challenge assumptions of self-interest and profit motives. By exercising the power to name, they reassign worth to that which is not normally monetized or valued. And, in their apparent surrender of control to their members, their communities, and the environment, they call attention to a range of values that neoliberal logics have abandoned.

All these efforts show human motivations that extend well beyond the self and the hereand-now. Overall, through a lens of power, we see that these initiatives are not only deliberately choosing to engage through "power with" rather than "power against" but in so doing are also actively demonstrating how social, economic, and ecological relations can be discursively reframed.

The broad uptake of these re-framings may help to renormalize meeting all basic needs and the policy evolution required for it. Indeed, Classens, McMurtry, and Sumner (2014) state, "Taken together, initiatives of the social economy provide a patchwork that may, when stitched together, create a means of overcoming the one-rule economy and lead towards a more just and sustainable food system" (p. 231).

However, the path between offering re-framings of human relations and effecting broadbased change is not automatic. Sonnino and Trevarthen-Griggs (2013) contend that, because social economy of food initiatives are centred in place-based relationships and work primarily through their communities, their potential for growth is limited mainly to replicability and knowledge sharing. Others identify various preconditions for social change. For example, social economy initiatives "must take into account the nuts and bolts of social economic organizing. In other words, the fundamental mechanics of social change initiatives must be sound" (Classens et al., 2014, p. 231). For Dordoy \& Mellor (2000) "a democratic provisioning system” (p. 60) requires an existing political basis to be in place first so that democracy can thrive. For McMurtry (2010), the social economy needs to define itself as a social and economic movement, 
not just a set of unrelated activities. Moving forward from the current research, it will be important to continue to explore the most effective routes that link the everyday activities and discourses of social economy projects to broader social change.

Our theoretical intervention is empirically grounded, but we recognize that our data originated from sources about a limited selection of social economy initiatives. Future research could also draw on and compare a wider range of initiatives embracing different worldviews and regional specificities. It could also engage with them directly about their relationship with impact assessment and what measurement means to them. The results of such inquiry might further illuminate impacts that fly under the (monetized) radar.

According to Guthman (2008), the effect of neoliberalization on agro-food activists (broadly defined), is to place "limits [on] the conceivable because it limits the arguable, the fundable, the organizable, the scale of effective action, and compels activists to focus on putting out fires" (p. 1180). While we agree that neoliberalization can work to constrain project capacity, we also see social economy initiatives not only fighting fires but also broadening the conceivable by sparking possibility and shedding light on more socially and environmentally sustainable worlds. Overall, we found that the SEOF initiatives work discursively not only to explain their own work, but also to offer up models of alternative framing of work, social relations, and value. Indeed, like local sustainable food projects in other studies (Andrée, Ballamingie, \& SinclairWaters, 2015; Sumner, 2012), they are not waiting for the state or corporations to move towards greater sustainability but are attempting to create the systems they want to see. In the process, they are going beyond their own environments to expand social imaginaries by providing models for what is possible.

\section{References}

Andrée, P., Ballamingie P., \& Sinclair-Waters, B. (2015). Neoliberalism and the making of food politics in Eastern Ontario. Local Environment, 20(12), 1452-1472

Andrée, P. Clark, J.K. Levkoe, C.Z. Lowitt, K., \& Johnston, C. (2019). The governance engagement continuum: Food movement mobilization and the execution of power through governance arrangements. In P. Andrée, J.K. Clark, C.Z. Levkoe, \& K. Lowitt (Eds.) Civil society and social movements in food system governance. New York: Routledge.

Allen, P. (2010). Realizing justice in local food systems. Cambridge Journal of Regions, Economy, and Society, 3(2), 295-308.

Allen, L. (2015). Ontario east alternative land use services program: A case study. Retrieved from http://nourishingontario.ca/the-social-economy-of-food/case-studies-subversionsfrom-the-informal-and-social-economy/ 
Anderson, P., \& Whetung, J. (2018). Black duck wild rice: A case study. Retrieved from http://nourishingontario.ca/the-social-economy-of-food/case-studies-subversions-fromthe-informal-and-social-economy/.

Canadian CED Network. (n.d). The social economy. Retrieved from https://ccednetrcdec.ca/en/page/social-economy-0.

Classens, M., McMurtry, J.J., \& Sumner, J. (2014). Doing markets differently- FoodShare's Good Food Markets. In J. Quarter, S. Ryan, \& A. Chan (Eds.) Social purpose enterprises: Case studies for social change. University of Toronto Press.

Davies, A. (2019). Urban food sharing: Rules, tools and networks. Bristol: Policy Press.

Delind, L. (2011). Are local food and the local food movement taking us where we want to go? Or are we hitching our wagons to the wrong stars? Agriculture and Human Values, 28, 273-283.

DeVault, M. (1990). Talking and listening from women's standpoint: Feminist strategies for interviewing and analysis. Social Problems, 37(1), 96-116.

Dordoy, A., \& Mellor, M. (2000). Ecosocialism and feminism: Deep materialism and the contradictions of capitalism. Capitalism, Nature, Socialism, 11(3), 41-61.

Entman, Robert M. (1993). Framing: Towards clarification of a fractured paradigm. Journal of Communication, 43(4): 51-58.

Gannon, S., \& Davies, B. (2012). Postmodern, post-structural and critical theories. In S.N. Hesse-Biber (Ed.) The handbook of feminist research: Theory and praxis $\left(2^{\text {nd }}\right.$ ed.). Los Angeles: Sage Publications.

Gitlin, T. (1980). The whole world is watching: Mass media in the making and unmaking of the new left. Berkeley: University of California Press.

Guthman, J. (2008). Neoliberalism and the making of food politics in California. Geoforum, 39(3), 1171-1183.

Harstock, N. (1989). Postmodernism and political change: Issues for feminist theory. Cultural Critique, 14(1), 15-33.

Hooks, B. (1991). Theory as liberatory practice. Yale Journal of Law \& Feminism, 4(1), 1-12.

Kakegamic, R., Nelson, C., \& Levkoe, C.Z. (2017). Willow Springs Creative Centre: A case study. Retrieved from http://nourishingontario.ca/the-social-economy-of-food/casestudies-subversions-from-the-informal-and-social-economy/

Karlberg, M. (2005). The power of discourse and the discourse of power: Pursuing peace through discourse intervention. International Journal of Peace Studies, 10(1), 1-23.

Kruks, S. (2001). Retrieving Experience: Subjectivity and Recognition in Feminist Politics. Ithaca, NY: Cornell University Press.

Martin, M.A. (2016). DIG (Durham Integrated Growers for a Sustainable Community): A case study. Retrieved from: http://nourishingontario.ca/dig-durham-integrated-growers-for-asustainable-community/. 
McMurtry, J.J. (2010). Introducing the social economy in theory and practice. In J.J. McMurtry (Ed.) Living Economies: Perspectives on Canada's Social Economy. Toronto: Edmond Montgomery Publications.

Mount, P., \& Andrée, P. (2013). Visualising community-based food projects in Ontario. Local Environment, 18(5), 578-591.

Nourishing Communities. (2018). The social economy of food: Informal, under-recognized contributions to community prosperity and resilience. Retrieved from http://nourishingontario.ca/the-social-economy-of-food/.

Nourishing Communities. (2017a). Workshop - Subversions from the informal and social economy. Retrieved from http://nourishingontario.ca/the-social-economy-offood/workshop-subversions-from-the-informal-and-social-economy/.

Nourishing Communities. (2017b). Subversions from the informal and social economy: A workshop report. Retrieved from http://nourishingontario.ca/the-social-economyoffood/subversions-from-the-informal-and-socialeconomy-workshop-report/.

Peck, J., \& Tickell, A. (2002). Neoliberalizing space. Antipode, 34(3), 380-404.

Poitevin-Des Rivières, C. (2018). Hidden Harvest: A case study. Retrieved from http://nourishingontario.ca/the-social-economy-of-food/case-studies-subversions-fromthe-informal-and-social-economy/

Putnam, R. D. (2000). Bowling alone: Collapse and revival of American community. New York: Simon \& Schuster.

Quarter, J., \& Mook, L. (2010). An interactive view of the social economy. Canadian Journal of Nonprofit and Social Economy Research, 1(1), 8-22.

Sonnino, R., \& Trevarthen-Griggs, C. (2013). A resilient social economy? Insights from the community food sector in the UK. Entrepreneurship and Regional Development, 25, $272-292$.

Stephens, P., Nelson, C.H., Levkoe, C.Z., Mount, P., Knezevic, I., Blay-Palmer, A., \& Martin, M.A. (2019). A perspective on social economy and food systems: Key insights and thoughts on future research. Canadian Food Studies. This issue.

Stolz, W., Levkoe, C.Z., \& Nelson, C. (2017). Blueberry foraging as a social economy in Northern Ontario: A case study of Aroland First Nation, Arthur Shupe Wild Foods, Nipigon Blueberry Blast Festival, and the Algoma Highlands Wild Blueberry Farm and Winery. Retrieved from http://nourishingontario.ca/the-social-economy-of-food/casestudies-subversions-from-the-informal-and-social-economy/

Streuker, A., Levkoe, C., \& Nelson, C. (2017). The Cloverbelt local food co-op: A case study. Retrieved from http://nourishingontario.ca/the-social-economy-of-food/case-studiessubversions-from-the-informal-and-social-economy/

Sumner, J. (2012). Dining on the social economy: Local, sustainable food systems and policy development. Canadian Review of Social Policy, 67, 30-43). 
Thomas, M. (2015). Guelph Centre for Urban Organic Farming: A case study. Retrieved from http://nourishingontario.ca/the-social-economy-of-food/case-studies-subversions-fromthe-informal-and-social-economy/

Uluorta, H.M. (2009). The social economy: Working alternatives in a globalizing era. New York: Routledge

Vliegenthart, R., \& van Zoonen, L. (2011). Power to the frame: Bringing sociology back to frame analysis. European Journal of Communication, 26(2). 101-115.

Wakefield, S., Fleming, J., Klassen, C., \& Skinner, A. (2013). Sweet Charity, revisited: Organizational responses to food insecurity in Hamilton and Toronto, Canada. Critical Social Policy, 33(3), 427-450.

Worden-Rogers, N.J. (2015). Seed saving in Atlantic Canada: A case study. Centre for Sustainable Food Systems, Wilfrid Laurier University. Retrieved from http://nourishingontario.ca/the-social-economy-of-food/case-studies-subversions-fromthe-informal-and-social-economy/ 